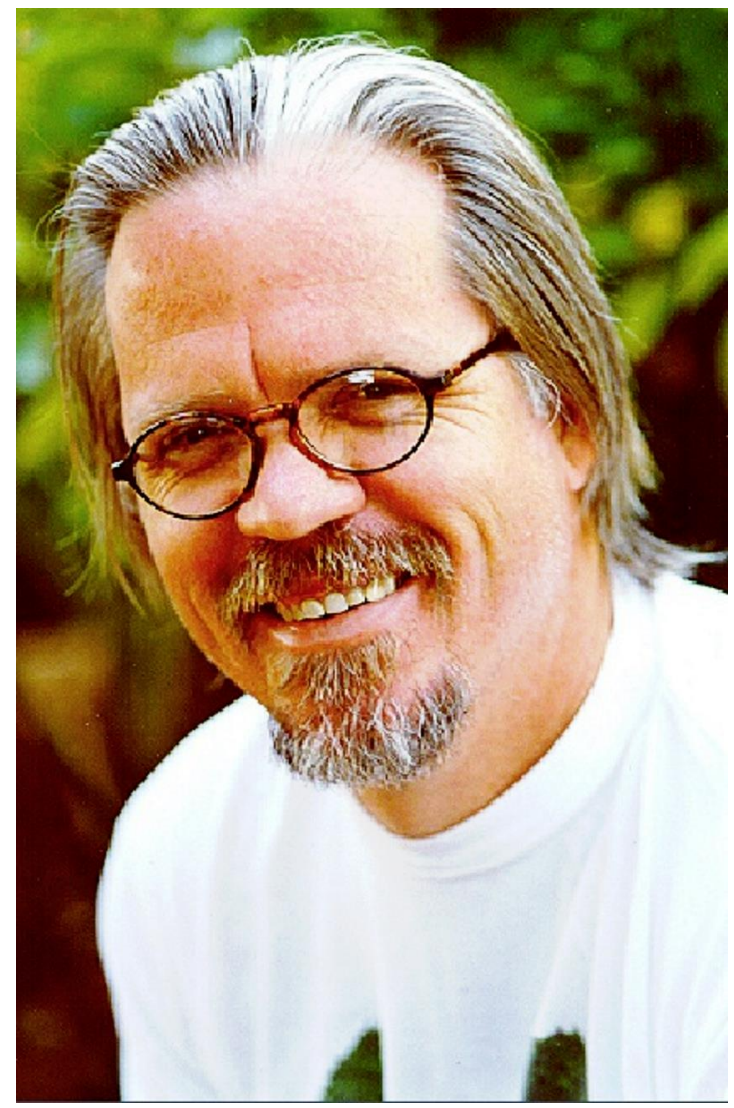

Foto divulgação

\title{
O suco da laranja seleta
}

\section{Nicolas Maria von Behr}

\section{Por Regis Gonçalves}

Regis Gonçalves é escritor e jornalista. Autor dos livrosqueima de arquivo, Opus circus e Trama tato texto (poesia), atualmente prepara a edição de mais um livro de poemas e de outro que reunirá uma série de perfis de artistas e intelectuais publicados ao longo dos últimos dez anos na imprensa brasileira. É colaborador de jornais e revistas, dedicando-se também a trabalhos no campo editorial.

Com a edição de Laranja Seleta, uma coletânea de sua produção ao longo de 30 anos, o poeta Nicolas Behr chega pela primeira vez ao mercado pela via de uma editora comercial - Língua Geral, Rio de Janeiro -, ao mesmo tempo que comemora 50 anos 
de idade e 29 livros publicados - mimeografados ou impressos em offset - sempre distribuídos pelo autor.

Mas isso não chega a impressionar o velho poeta marginal, que desde 1977, quando lançou Iogurte com farinha, o primeiro livrinho mimeografado, ainda hoje seu best-seller (vendeu oito mil exemplares de mão em mão), vem trilhando um caminho próprio, sem concessões, e praticando uma poesia originalíssima, que o coloca entre os ícones de sua geração. Prolífero, já planeja publicar Bagaço de Laranja, com os poemas que não entraram na edição "oficial", além de um volume que ele chama de "livrão inédito", A balada do falso poeta.

Nicolas Maria von Behr, ou simplesmente Nik para os amigos, nasceu em Cuiabá, Mato Grosso, em 1958. Estudou o primário com padres salesianos, em Diamantino, onde os pais eram fazendeiros. Mudou-se para a Brasília em 1974, onde vive até hoje. Não é um acontecimento fortuito: Brasília tornou-se o lugar de onde Nicolas fala, o espaço de eixões e super quadras onde sua poesia está entranhada.

Esse lugar, contudo, nada tem a ver com a Brasília que todos conhecemos como locus do poder e das barganhas políticas. Nicolas fala de uma Brasília mítica e não menos verdadeira, que ele chamou Braxília, onde o poeta interroga a contradição entre o espaço público a ser ainda construído e os blocos de concreto cercados pela miséria das cidades-satélites.

Mas deixemos o poeta falar de seu trabalho e de si mesmo, em entrevista concedida a Regis Gonçalves, exclusiva para esta publicação. Para saber mais sobre ele, acesse o site http://www.nicolasbehr.com.br/

\section{Regis Gonçalves - Que critério orientou você na escolha dos poemas de Laranja seleta? São poemas representativos dos vários períodos de sua produção ou apenas aqueles que você considera melhores?}

Nicolas Behr - As duas coisas, numa tentativa equilibrada de passar uma visão bem ampla da minha produção poética de 1977 a 2007. O livro tem os poemas "clássicos" (modéstia incluída) e os que tiveram mais repercussão, que foram mais publicados. Enfim, é um livro bonitinho, (mas não careta), bem feito. E pra ficar, espero.

\section{Você tem publicado em livro (edições quase sempre alternativas), mas também na Internet. Como você avalia a recepção dos leitores em cada uma dessas mídias?}


Pra mim, vale o que está escrito. O meio não interessa. Ou melhor: interessa pouco. O que vale é a mensagem. Muitos acham que, então, eu deveria ser carteiro ou mandar meus poemas pelo correios. Eu me concentro muito no conteúdo, no que está dito. Muitas vezes, as pessoas colocam tantos balangandãs nos poemas que o conteúdo do texto desaparece.

Atualmente, sua produção tem sido mais ou menos intensa do que época da poesia marginal? Por quê?

Escrevia muito mais nos anos 70. Hoje o poema já vem quase pronto, digamos. E o processo de remoção de entulho literário não é mais tão braçal, mas mental. Mas tenho escrito muito e rasgado pouco, o que é preocupante.

Na poesia que você faz hoje, há alguma temática que the interessa mais especialmente?

Há duas temáticas bem claras: Brasília e minha infância em Diamantino, Mato Grosso. Hoje tenho dois livros inéditos sobre esses dois temas. E gosto de trabalhar assim: reunindo poemas em livros temáticos. Mas tenho também um material não classificável que vai pro livrão, um inédito chamado $A$ balada do falso poeta.

- que você considera que mudou em sua poesia, desde que começou a escrever? Ou nada mudou?

Claro que mudou: eu mudei, minha poesia mudou. Neste ano vou fazer 50 anos. Meu Deus, quem diria que um dia eu faria 50 anos! Mas continuo um garoto, apesar do cansaço físico ao subir uma escada muito longa. Minha poesia está mais existencialista, acredito. Sou limitado pelo meu estilo, um tipo de amarra. Tentar romper esses limites, continuando a ser fiel a mim mesmo, é meu desafio.

\section{E o que mudou (ou nada mudou) na poesia brasileira em geral?}

Acredito que muita coisa mudou na poesia brasileira desde que comecei a publicar, em 1977. A começar pelos novos meios: a internet, os blogs, a facilidade de veicular poesia pelo computador (a internet é o mimeógrafo de hoje). Tudo se atomizou, explodiu. E todos ficam procurando um rótulo, pois o homem é um classificador. Quer classificar pra entender. Mas, hoje, tá tudo muito confuso, e isso é bom. 
Sua imagem de poeta está intimamente relacionada a Brasília. Você se incomoda com o fato de ser tão identificado à cidade? Afinal, que Brasília é essa que você canta em verso?

Ah, hoje sou um autor nacional, editado por uma editora do Rio de Janeiro, com distribuição por todo o país. Claro, somos classificadores: Nicolas Behr, aquele poeta marginal lá de Brasilia. A cidade me traumatiza positivamente. Acho que, se morasse em Veneza, Buenos Aires ou Belo Horizonte, também escreveria sobre a cidade. Mas Brasilia é uma cidade poeticamente virgem. Escreveu-se e se escreve pouco sobre a cidade. Então, sou um privilegiado, por estar aqui praticamente desde o começo. O que são 13 anos na vida de uma cidade? Também acho que é bom se identificar com um lugar, deixar uma marca, digamos. Claro, não sou nem nunca serei o poeta oficial de Brasília, não é a Brasília do poder que eu canto. Eu canto a Brasilia rebelde, roqueira, criativa, underground. Que um dia vai expulsar o poder daqui. Quando Brasília deixar de ser capital, vai se chamar Braxilia.

Cite dois ou três nomes atuais da poesia brasileira que agradam a seu paladar.

Atuais: Chacal, Francisco Alvim e Paulo Leminski. Sei que você quer nomes novos. Não os tenho. Sorry.

Belo Horizonte, janeiro de 2008. 